\title{
METAFORY I NEOLOGIZMY WSPÓŁCZESNEGO JĘZYKA NAUK SPOŁECZNYCH I EKONOMICZNYCH
}

\section{WSTĘP}

Rzeczywistość, w której żyjemy, cechują zmiany, przede wszystkim jej stanu i struktury. Wśród zmian stanu zasadniczą rolę odgrywa rozwój. Na naszych oczach rozwija się niemal wszystko. Także język, zarówno potoczny, codzienny, literacki, jak i naukowy. Pojawia się wiele nowych słów, terminów, pojęć, których znaczenie trudno czasami jednoznacznie zinterpretować. Maja one postać metafor, zapożyczeń z języków obcych, a także tłumaczeń obcojęzycznych wyrażeń na język polski. Częste jest także mnożenie i rozwijanie pojęć egzystujących w używanym języku, które nie tylko niepotrzebnie komplikują stosowane słownictwo, ale utrudniają zrozumienie oraz międzyludzką komunikację w tak ważnej sprawie, jaką jest wiedza naukowa. Szczególna obfitością metafor, neologizmów i innego rodzaju innowacji terminologiczno-pojęciowych cechuje się język nauk społecznych i ekonomicznych, z którego korzysta biernie i czynnie autor niniejszego artykułu.

Celem niniejszej publikacji jest prezentacja i generalna ocena współczesnego języka naukowego, konkretnie nauk społecznych i ekonomicznych. Sa oczywiście zwolennicy nieustannego powiększenia zasobów słownictwa języka naukowego, przywołujący przy tej okazji wieszcza Juliusza Słowackiego, który napisał „Chodzi mi o to, aby język giętki / Powiedział wszystko, co pomyśli głowa" ${ }^{1}$. Wersy te trzeba jednak interpretować w całości. Oczywiście język giętki to język żywy, możliwie najlepiej opisujący daną rzecz, zdarzenie czy też proces, ale jednocześnie opisujący to, co pomyśli głowa. Pomyśli głowa, czyli przed zajęciem stanowiska przeprowadzi się proces myślowy, a nie pisze lub mówi to, co przychodzi do głowy i bezrefleksyjnie prowadzi do bezsensownego słowotwórstwa. Myślenie jest zaś podstawą tworzenia zasobów wiedzy, a zatem istota dociekań naukowych ${ }^{2}$. Chodzi także o zastanowienie się nad sensem nieustannego powiększania słownictwa języka naukowego, co jak się wydaje, prowadzi raczej do nieporozumień niźli lepszego zbadania, opisania i zrozumienia badanej rzeczywistości. Jest to być może subiektywna ocena. Wydaje się jednak, że dynamika rozwoju słownictwa w polskim języku nauko-

\footnotetext{
1 Jest to werset z poematu Beniowski (Pieśń IV) Juliusza Słowackiego.

${ }^{2}$ Taki wniosek wyprowadzić można z zawartego w Rozprawie o metodzie R. Descartes'a (1637) stwierdzenia Myślę, więc jestem (łac. cogito ergo sum).
} 
wym, zwłaszcza nauk społeczno-ekonomicznych, jest odwrotnie proporcjonalna do postępu naukowego, dokumentowanego przez publikacje. Przedmiotem szczególnej uwagi w niniejszym artykule będą metafory językowe, neologizmy i inne, różnego rodzaju nowe słowa (pojęcia, terminy) oceniane w kontekście semantyki i pożądanych właściwości języka naukowego. Cechą współczesnego języka jest jego nieustanny rozwój, w tym ciagłe wzbogacanie słownictwa. To jednak, co ma dobre strony w języku potocznym, codziennym (wyłączając oczywiście wulgaryzmy), przede wszystkim jednak w literackim (metafory), nie zawsze jest dobre w języku naukowym, którego przekaz musi być jednoznaczny i w którym nie ma miejsca na domysły i indywidualne interpretacje. $\mathrm{W}$ tym miejscu na myśl przychodzi tym razem werset ewangeliczny: „Wasza mowa niech będzie tak - tak, nie - nie. A co nadto z zepsucia jest"', z którego wyprowadzić można nie tylko jednoznaczność języka naukowego, jako pożądana jego cechę (tak - tak, nie - nie), ale także to, co jest istotą badań naukowych, czyli odróżnienie prawdy od fałszu, dobra od zła, przyzwolenia od zakazu, prawa od bezprawia itp.

Niniejszy artykuł jest zapewne kontrowersyjny, choćby z tego powodu, że zwolenników wzbogacania języka naukowego jest całkiem sporo ${ }^{4}$. Podjęcie tego tematu uzasadnić można jednak, jak się wydaje, z jednej strony konieczna troską o czystość i poprawność języka narodowego, w tym także naukowego, który ma być ciągle doskonalonym narzędziem komunikacji międzyludzkiej", a z drugiej - przeświadczeniem, że wiele wprowadzanych do języka naukowego pojęć (terminów) niczego nie wnosi, ale prowadzi do jego (języka) bezsensownej inflacji terminologiczno-pojęciowej ${ }^{6}$. Jeśli jednak prezentowane treści nie trafią do świadomości czytelników, to niech przynajmniej będą przedmiotem zamyślenia i refleksji.

\section{JĘZYK NAUKOWY I JEGO POŻĄDANE CECHY}

W literaturze znaleźć można wiele różnych cech, jakimi charakteryzować powinien się język naukowy. Wśród najczęściej spotykanych wymienić należy: 1) jasność, 2) jednoznaczność, 3) prostotę, 4) logiczność, 5) zwięzłość oraz 6) zrozumiałość. Wymienione cechy nie tworzą zbioru rozłącznego, łączy je

${ }^{3}$ Mat 5, 37.

${ }^{4} \mathrm{Na}$ konieczność troski o język ojczysty i poprawność używanego przez uczonych języka naukowego zwracało uwagę wiele osób, w tym m.in. znakomity polski matematyk, jeden z ojców, słynnej w całym świecie matematycznej szkoły lwowskiej H. Steinhaus (por. M. Urbanek, Genialni. Lwowska szkoła matematyczna, Iskry, Warszawa 2014).

${ }^{5}$ Por. ustawa z 7 października 1999 r. o języku polskim (Dz. U. 1999, Nr 90, poz. 999), z której zapisu wynika jednak pewnego rodzaju dyspensa dla języka naukowego, odnosząca się jednak do zwyczajowo stosowanej terminologii naukowej (art. 11).

${ }^{6}$ Chodzi tu przede wszystkim o synonimy pojęć jednoznacznych i od dawna stosowanych oraz o takie tłumaczenia na język polski, w których przetłumaczony wyraz pochodny ma zupełnie inny sens od tak samo brzmiącego wyrazu podstawowego z języka polskiego (co zostanie przedstawione w dalszej części artykułu). 
bowiem pewnego rodzaju sieć relacji przyczynowo-skutkowych oznaczajacych, co oznacza, że jedna cecha decyduje o charakterze drugiej (np. prostota o zwięzłości, logiczność o jednoznaczności), a pięć pierwszych wymienionych w sumie decyduje o zrozumiałości języka. Można także przyjąć, że pięć pierwszych cech ma charakter jednostkowy, a szósta wydaje się cechą wynikowa, syntetyczną. Jest więc rzeczą oczywista, że takie właśnie cechy charakteryzować powinny w zasadzie każdy język, jeśli ma on być narzędziem międzyludzkiej komunikacji i porozumienia, a w sferze nauki - jednoznacznej oraz poprawnej interpretacji prezentowanych poglądów oraz wyników prowadzonych badań. Sprawa jest o tyle poważna, że w stosowanym języku naukowym mamy z jednej strony do czynienia z nieustannym powiększaniem liczby będących w użyciu terminów, które poza zbiorem nieporozumień i chaosem semantycznym niczego właściwie nie wnosza, a z drugiej - z wpływem prowadzonego słowotwórstwa na charakter języka, w konsekwencji na jego, nie zawsze najlepsza, ocenę, przynajmniej w nawiązaniu do pożądanych, wymienionych uprzednio cech (tego języka).

Jest z pewnościa wiele przyczyn, nie zawsze sensownego, poszerzania słownictwa języka naukowego. Pierwsza jest bez wątpienia internalizacja języka polskiego, będąca pewnego rodzaju presja, której ulegają naukowcy, a która ma na celu narzucenie „zewnętrznych” pojęć, norm, także poglądów, stosowanych często poza daną dyscypliną naukowa, poza stosowanym językiem naukowym, także poza językiem narodowym. Presji tej zbyt łatwo poddają się środowiska naukowe, prawdopodobnie $\mathrm{z}$ tego powodu, że ma to być wyrazem nowoczesności i postępu (w prowadzonych badaniach), a często jest to zwykłym wpisaniem się w poprawność polityczna, która nie omija także sfery nauki. Nie bez znaczenia jest w tym przypadku nadmierna metaforyzacja języka, której autorami są uznawane w świecie autorytety naukowe. Można zapewne mówić zarówno o globalizacji języka naukowego, jak i o globalizacji jako czynniku rozwoju słowotwórstwa naukowego, dla których, jak się wydaje, nie ma granic w żadnym z aspektów.

Inna z przyczyn obserwowanego stanu rzeczy jest brak w języku polskim słów pozwalajacych w miarę jednoznacznie oddawać sens terminów obcojęzycznych, co w pewnym sensie jest zrozumiałe. Sytuacja taka często jednak prowadzi do tworzenia nowych pojęć, będących pewnego rodzaju „pochodnymi” wyrazów podstawowych (sustensywność, rozwój sustensywny, rezyliencja), do nadawania istniejacym w języku polskim wyrazom (pojęciom) nowego znaczenia (np. redundancja, kontrybucja itp.) lub do zastępowania, nie zawsze szczęśliwie, terminów obcojęzycznych, tłumaczeniami na język polski (smart jako „inteligentny”, cohesion jako „likwidowanie różnic”, „zmniejszanie dysproporcji” itp.), co często trudno przyjąc jako rozwiąanie sensowne. Rzeczą wręcz fatalna jest wprowadzanie do języka naukowego wyrazów $\mathrm{w}$ znaczeniu innym od ugruntowanego w języku codziennym. W tym ostatnim przypadku zawsze powinno rodzić się pytanie, czy nie lepiej posłużyć się pojęciem oryginalnym, wiedząc, jaki jest jego semantyczny sens, niźli tworzyć nowe słowa, niemające z językiem polskim wiele wspólnego, lub stosować tłumaczenia wymagające dodatkowych wyjaśnień. 
Kolejną przyczyną rozkwitu słowotwórstwa w polskim języku naukowym jest przeświadczenie o tym, że liczba stosowanych metafor i różnego rodzaju neologizmów jest dowodem na oryginalność, nowoczesność oraz wartość naukową tworzonego tekstu względnie projektu badawczego. Właśnie prawdopodobnie $\mathrm{z}$ takim przekonaniem formułowane sa tematy wielu projektów badawczych NCN-u (o wysokim współczynniku sukcesu), pełne nieporozumień, pozorów nowoczesności, a często i braku logiki. Czytając tematy akceptowanych do finansowania projektów oraz ich opisy, trudno nie mieć wątpliwości co do zakresu wiedzy z logiki oraz metodologii, zarówno ogólnej, jak i dotyczącej danej dyscypliny naukowej, jaka prezentuja niektórzy autorzy zgłaszanych projektów. Zupełnie inną sprawą jest uczciwość oraz sumienność oceny projektów przygotowanych często z wielkim trudem i nakładem pracy, jednakże opatrzonych tradycyjnym tytułem i napisanych takim samym językiem, czyli dość ubogim w neologizmy językowe. Bardzo poważnym źródłem zaśmiecania języka naukowego jest język mediów oraz język stosowany w dokumentach urzędowych, przenikający do języka naukowego, często bezkrytycznie, ale i z konieczności przyjmowany w środowiskach naukowych (konieczność odniesienia się do konkretnego zapisu). Co się tyczy dokumentów, to chodzi zarówno o obowiąujace, uchwalane krajowe akty prawne, jak i o dokumenty Unii Europejskiej, prezentowane w polskiej wersji językowej. Szkoda, że zapisy tych dokumentów nie sa, przed ich uchwaleniem, poddane weryfikacji logicznej, językowej i prawniczej. No i jest jeszcze moda, której trudno się oprzeć lub za która wypada nadążać także w języku naukowym. Wszystko to razem jest przyczyną w sumie bezsensownego powiększania słownictwa języka naukowego, które staje się swoistą nowomowa, znaną uprzednio jedynie z języka propagandy.

Maniera tworzenie nowych pojęć, rozszerzenie znaczenie pojęć znanych oraz wprowadzenie obcojęzycznych dotyczy niemal wszystkich dyscyplin naukowych i znana jest prawdopodobnie od dawna. Wniosek taki można wyprowadzić w nawiązaniu do sformułowanej już w XIII w. przez angielskiego franciszkanina Williama Ockhama (1285-1347 lub 1349) zasady zwanej brzytwa Ockhama, podawanej najczęściej w sformułowaniu „nie należy mnożyć bytów ponad potrzebę” lub „nie mnożyć bytów bez potrzeby”7. Brzytwa Ockhama nazywana jest zasada ekonomii myślenia, zgodnie z która w wyjaśnianiu zjawisk należy dążyć do prostoty, stosując zasadę wybierania takiej drogi postępowania, która zawierać będzie jak najmniejsza ilość założeń wstępnych i pojęć ${ }^{8}$. Choć poglądy Ockhama w tym zakresie były i sa uznawane przez wielu uczonych, zwłaszcza filozofów, za kontrowersyjne, to w naukach, zwłaszcza w tzw. podstawowych i empirycznych, przyjmowane

\footnotetext{
${ }^{7}$ Oryginalne sformułowanie tego franciszkańskiego filozofa, logika i teologa miało postać zapisu: „Nie wolno przyjać niczego bez uzasadnienia, że ono jest, musi ono być oczywiste albo znane na mocy doświadczenia, albo zapewnione przez autorytet Pisma Świętego”. Dopiero później pojawiły się inne sformułowania tej zasady (przez J. P. De Corka, J. Clauberga, W. Hamiltona $\mathrm{i}$ innych), w tym podane przykładowo w tekście.

${ }^{8}$ R. Panaccio, Ockham, w: E. Craig (ed.), Routlegde Encyklopedia of Philosophy, Routledge, London-New York 1998; R. Heinzmann, Filozofia średniowieczna, tłum. P. Domański, Wydawnictwo „Antyk”, Kęty 1999.
} 
sa jako wysoce użyteczne, co wydaje się potwierdzać nieustanny rozwój nauk ścisłych oraz techniki i technologii. Co więcej, brzytwa Ockhama traktowana jest często jako narzędzie walki z pseudonauka, a branie jej pod uwagę uważane jest za przejaw pragmatyzmu, użyteczności i odpowiedzialności twórczej.

\section{METAFORY JĘZYKA NAUKOWEGO JAKO LOGICZNA KONSEKWENCJA ROZWOJU NAUKI}

Jak to już napisano, język naukowy wzbogacają metafory, które najczęściej definiuje się jako językowe środki wyrazu. W metaforze obce sobie słowa tworzą związek frazeologiczny o nowym znaczeniu. Jako takie konstrukcje słowne, z języka literackiego, gdzie są dość powszechnie stosowane, przez język kultury i życia codziennego, trafiły także do języka naukowego. Wyrażany jest, w zasadzie niekwestionowany pogląd, że metafora wzbogaca użytkowany język, świadczy bowiem o jego żywotności i rozwoju. Tworzenie metafor i ich stosowanie nie jest, zwłaszcza w języku potocznym (codziennym), niczym złym.

$\mathrm{Z}$ nieco inną sytuacją mamy jednak do czynienia w języku naukowym, w którym zastosowana jest nie tylko przedmiotem indywidualnej refleksji, ale przez dowolność interpretacji często prowadzi do niejasności i nieporozumień. Jest to o tyle ważne, że świat współczesny jest, w coraz większym stopniu, postrzegany i opisywany za pomoca metafor ${ }^{9}$. Szczególnie wiele nowych metafor pojawiło się w języku naukowym w okresie postmodernizmu. Właśnie wtedy zyskały one na znaczeniu nie tylko w kształtowaniu wiedzy, stajac się sposobem czy rodzajem prowadzenia dyskusji naukowej, lecz także formą wyrażania myśli ${ }^{10}$. Nie jest to jednak powszechny punkt widzenia. Niektórzy autorzy twierdza, że metafory, jako wynalazek semantyki oparty na psychologicznych i filozoficznych implikacjach, mimo pewnej roli w nauce, tworzą jednak język sztuczny ${ }^{11}$. Formułowane sa ponadto zastrzeżenia oraz pojawiają się wattpliwości co do przydatności pojawiających się i stosowanych metafor w kształtowaniu wiedzy ${ }^{12}$. Mimo tych i innych zastrzeżeń zapewne przyjąć trzeba, że metafora jest raczej składnikiem języka, a nie procesu myślenia - i tak powinna być traktowana, także w nauce.

${ }_{9}^{9}$ G. Lackoff, The contemporary theory of metaphor, w: A. Ortony (ed.), Metaphor and Tought, CUP, Cambridge 1993, s. 202-251; G. Lakoff, M. Johnson, Metafory w naszym życiu, PIW, Warszawa 1998.

${ }^{10}$ Y. J. Barnes, Metaphors and conversations in economic geography: Richard Rorty and the gravity model, „Geografiska Annaler” 73B, 1991, s. 111-120; Y. J. Barnes, M. R. Curry, Postmodernism in economic geography: metaphor and the construction of alterity, „Environment and Planning. D. Society and Space” 10, 1992, s. 57-68; R. Rorty, Filozofia jako nauka, jako metafora i jako polityka, w: A. Szahaj (red.), Między pragmatyzmem a postmodernizmem, UMK, Toruń 1995.

${ }_{11}$ C. M. Turbayne, The Myth of Metaphor, YUP, Oxford 1962.

${ }_{12}$ Z. Chojnicki, Koncepcje $i$ zastosowanie metafory $w$ geografii spoteczno-ekonomicznej, w: H. Rogacki (red.), Problemy interpretacji wyników metod badawczych stosowanych w geografii spoteczno-ekonomicznej $i$ gospodarce przestrzennej, Bogucki Wydawnictwo Naukowe, Poznań 2003. 
W nauce metafory występuja jako powiązane $\mathrm{z}$ sobą domeny pojęciowe, z których jedna jest domeną źródłowa, a druga - docelowa. W ten sposób mniej konkretne pojęcie jest objaśniane przez inne znane i bardziej konkretne. Innymi słowy, nowe metafory są konstruowane z pojęć znanych, dostępnych, funkcjonujących zarówno w języku naukowym, jak i potocznym. Zawsze tworzone sa z dostępnego materiału językowego. W kognitywistycznej teorii metafor zakłada się, że relacje między metaforą źródłową a docelową sa nieodwracalne. W procesie tworzenia metafor zawsze powinno jednak chodzić o to, aby nowa metafora ułatwiała poznanie i lepiej objaśniała rzeczywistośćc ${ }^{13}$. Taka rolę pełnia jednak przede wszystkim metafory semantyczne, nie zaś retoryczne. Te pierwsze, semantyczne, poprzez heurystyczna i odkrywcza rolę, wnoszą pewną innowacyjność w tworzenie podstaw teorii i metodologii różnych dziedzin nauki ${ }^{14}$. Szczególnej roli metafor języka naukowego upatrywać zatem należy w (1) budowie nowych pojęć teoretycznych oraz (2) modelowaniu teoretycznym ${ }^{15}$. Ponieważ pełnią taką rolę, metafory są wykorzystywane zarówno w tworzeniu nowych paradygmatów rozwoju nauki, jak i w modelowaniu obserwowanej rzeczywistości. Należy w tym miejscu dodać, że nie wszystkie nowo utworzone metafory wzbogaciły język naukowy i spełniły pokładane w nich nadzieje. Po prostu nie sprawdziły się lub nie zakorzeniły w żywym i wzbogacanym języku naukowym. Po prostu, używając metafory, ich $c y k l \dot{z} y$ ciowy był zbyt krótki. Te drugie, tj. metafory retoryczne, wprawdzie wzbogacają język, czyniąc go bardziej różnorodnym i pojemnym - jednak tylko to.

Jak to już napisano na wstępie, metafory wzbogacają nie tylko język potoczny oraz literacki, lecz także naukowy. Każda z metafor, bez względu na język, na pewien czas staje się nowym jego składnikiem. W wielu przypadkach, co dotyczy także sfery nauki, jednak często języka sztucznego. W takiej sytuacji nie będą sposobem myślenia, choćby z tego powodu, że pierwszoplanową i najważniejszą cechą metafory nie jest jej sens, a użyteczność ${ }^{16}$. W gruncie rzeczy metafory ciagle pozostają wynalazkiem semantyki, opartym przede wszystkim na implikacjach psychologicznych i filozoficznych ${ }^{17}$.

Szczególne bogactwo metafor zawiera język nauk społecznych, za ich pomoca bowiem stosunkowo łatwo jest postrzegać i opisywać życie społeczne. Jest ich wiele, a jaka jest ich różnorodność, niech pokaże przykładowe jedynie ich wyliczenie. W odniesieniu do gospodarki wskazać można na tego rodzaju metafory, jak: $\dot{z} y c i e$ gospodarcze, elastyczność produkcji, elastyczność popytu, potencjat gospodarczy, bieguny wzrostu, wehikuty rozwoju, hamulce rozwoju, cykl życia produktu, inkubator przedsiębiorczości, środowisko biznesu, regiony uczace sie, gospodarka oparta na wiedzy, gospodarka kreatywna, przemyst turystyczny; natomiast w odniesieniu do życia społecznego, politycznego czy

${ }^{13}$ G. Lackoff, op. cit.; idem, M. Johnson, op. cit.; T. S. Kuhn, The Structure of Scientific Revolutions (enlarged), UCP, Chicago 1970; idem, Dwa bieguny: tradycja i nowatorstwo w badaniach naukowych, PIW, Warszawa 1985; idem, Metaphor in science, w: A. Ortony (ed.), op. cit., s. 405-419.

${ }_{14}$ Z. Chojnicki, Koncepcje $i$ zastosowanie metafory..., passim.

15 Ibidem.

${ }^{16}$ Y. J. Barnes, op. cit.; Y. J. Barnes, M. R. Curry, op. cit.

17 C. M. Turbayne, op. cit.; G. Lakoff, op. cit. 
orientacji ideologicznej, przykładowo: propaganda sukcesu, nowomowa, targowisko próżności, poprawność polityczna, podpalanie państwa, pedagogika wstydu, partyjny beton, homo sovieticus, moherowe berety, lemingi itp. Oczywiście nie wszystkie z wymienionych powyżej metafor mają charakter naukowy i wzbogacaja język nauki. Wiele z nich wpisało się jednak do tego języka właśnie przez wspomnianą uprzednio użyteczność. Użyteczność tę wykazuja przede wszystkim w procesie tworzenia nowych pojęć teoretycznych oraz $\mathrm{w}$ modelowaniu teoretycznym badanej rzeczywistości ${ }^{18}$, w tym także, a może przede wszystkim, w nazywaniu nowych paradygmatów oraz budowie nowych modeli.

\section{PARADYGMATY I MODELE}

W obiegu naukowym funkcjonuje wiele, nawet kilkadziesiąt definicji czy pojmowania pojęcia „paradygmat”, wprowadzonego do języka naukowego przez Thomasa S. Kuhna, co jest związane przede wszystkim z przyjmowanym punktem widzenia (ale także z innymi czynnikami) oraz dziedzina wiedzy, na potrzeby której definicja paradygmatu i sam paradygmat, zostały sformułowane ${ }^{19}$. W najbardziej ogólnym ujęciu, paradygmatem jest sposób widzenia rzeczywistości przyjmowany w danej dziedzinie nauki przez pewne wspólnoty badaczy, który charakteryzuje (tworzy) zbiór przyjmowanych pojęć i teorii, mających swoje umocowanie w tradycji i obowiąujacej praktyce ${ }^{20}$. Paradygmat jest ponadto traktowany jako wzorzec prowadzenia badań naukowych względnie schemat rozwiązywania problemów naukowych ${ }^{21}$. Przyjmowane w danym paradygmacie jego składniki staja się pewną tradycja badawczą i trwają dopóty, dopóki nie zostaną zastapione przez nowe, oparte na innych założeniach. W ten sposób zarówno dane obserwacyjne, jak i kryteria ocen istniejących teorii (także budowanych) stają się zależne od przyjmowanych paradygmatów ${ }^{22}$. Te zaś są „niewspółmierne”, a ich przekształcenie w czasie rewolucji naukowych raczej nie dokonuje się za sprawą logicznej argumentacji, lecz pewnego rodzaju namysłu czy „nawrócenia” ${ }^{23}$. Wydaje się, że w każdej dziedzinie nauki (uprawianej przez wspólnoty naukowe) w pewnych okresach (od jednej rewolucji naukowej do kolejnej) przyjmowane są określone paradygmaty, które - jak się wydaje - dotyczyć moga także rozwoju regionalnego i lokalnego (sposób widzenia rzeczywistości, przyjmowane założenia, wzorce prowadzenia badań, sposoby rozwiązywania problemów). To w ramach

\footnotetext{
${ }_{18}$ Por. Z. Chojnicki, Koncepcje i zastosowanie metafory..., passim.

19 T. S. Kuhn, The structure of scientific...; idem, Dwa bieguny..., passim.

${ }^{20}$ T. S. Kuhn, The structure of scientific...; idem, Dwa bieguny, tradycja...; idem, Metaphor in science...; J. Barbour, Mity, modele, paradygmaty, Znak, Kraków 1984.

${ }^{21}$ J. Barbour, op. cit.; K. Jodkowski, Wspólnoty uczonych, paradygmaty i rewolucje naukowe, Wyd. UMCS, Lublin 1990.

${ }_{22}$ T. S. Kuhn, The structure of scientific...; idem, Dwa bieguny, tradycja...; idem, Metaphor in science..., passim.

${ }^{23}$ J. Barbour, op. cit.
} 
przyjmowanych paradygmatów tworzone sa idee, koncepcje, teorie i modele rozwoju. Bardzo często składnikami przyjmowanych paradygmatów są nowe pojęcia, w tym także metafory. Co więcej, bardzo często metafora jest nazwa paradygmatu, np. rozwój zrównoważony, rozwój endogeniczny, gospodarka oparta na wiedzy, gospodarka kreatywna, nowa geografia ekonomiczna, paradygmat decyzji przestrzennych itp. Takie jej zastosowanie nie budzi jednak zastrzeżeń, przede wszystkim z tego powodu, że paradygmat, którego dana metafora jest nazwa, jest zazwyczaj dobrze zdefiniowany. W gruncie rzeczy chodzi o zdefiniowanie składników danego paradygmatu. Definiowanie nowo wprowadzanych pojęć odgrywa zasadniczą rolę w dążeniu do uzyskania jednoznaczności i zrozumiałości języka naukowego i jest ważne, szczególnie przy ich (neologizmów) tworzeniu (wprowadzaniu do języka naukowego) ${ }^{24}$.

W znaczeniu ogólnym model jest: bądź to uproszczonym obrazem rzeczywistości (odwzorowaniem), bądź też jej projekcją (wzorcem). W pierwszym przypadku jest to odwzorowanie czegoś, co realnie istnieje, co można zaobserwować, opisać, przedstawić (w formie uproszczonej), natomiast w drugim jest to wzorzec, wzór, projekt tego, co zamierza się uzyskać. W każdym jednak przypadku, jak to już napisano, będzie to uproszczony obraz tego, co jest, lub tego, co zakłada się, że będzie. Odwzorowywane są bowiem zazwyczaj przede wszystkim najbardziej zasadnicze właściwości branych pod uwagę obiektów ${ }^{25}$. Istotą każdego modelu jest izomorfizm, czyli podobieństwo strukturalne pomiędzy odwzorowywanym przedmiotem (rzeczywistościa) a jej modelem. W nauce wyróżnia się różne kategorie modeli, np.: 1) teoretyczne, 2) analogowe oraz 3) matematyczne. Modelem teoretycznym jest pewien system słowny lub symboliczny, na wzór którego konstruuje się inny system lub który jest odwzorowaniem innego systemu. W modelu analogowym do formułowania zagadnień oraz tworzenia nowych pojęć względnie hipotez wykorzystywana jest analogia z innych dziedzin. Przykładem jest tzw. fizyka społeczna, w ramach której w odniesieniu do procesów społecznych formułowane sa hipotezy analogiczne do przyjmowanych w fizyce. Natomiast $\mathrm{w}$ modelu matematycznym wyraża się czy odwzorowuje w formie matematycznej konkretną sytuację problemową ${ }^{26}$. W innej klasyfikacji wyróżnia się nieco inne kategorie modeli: 1) doświadczalne (empiryczne), 2) logiczne, 3) matematyczne oraz 4) teoretyczne ${ }^{27}$. W wielu modelach stosowane sa nowe pojęcia, w tym metafory. Co więcej, wskazuje się na pewne podobieństwo modeli i metafor. Autor niniejszego tekstu przyjmuje jednak, że to w ramach przyjmowanych paradygmatów definiowane i budowane są określone modele,

${ }^{24}$ Niestety termin paradygmat jest aktualnie dość dowolnie używany w języku naukowym, w znaczeniu dalekim i zdecydowanie bardziej rozmytym od sformułowania Kuhna. Praktycznie paradygmatem może być nazwane wszystko, co wskazuje, że język naukowy schodzi na semantyczne manowce (to też jest metafora).

${ }_{25}$ Z. Chojnicki, Zastosowanie modeli grawitacji $i$ potencjału $w$ badaniach przestrzenno-ekonomicznych, Studia Komitetu Przestrzennego Zagospodarowania Kraju PAN 14, Warszawa 1966; R. L. Ackoff, Decyzje optymalne w badaniach stosowanych, PWN, Warszawa 1969; J. Parysek, Wrowadzenie do gospodarki przestrzennej, WN UAM, Poznań 2005.

${ }_{26}$ Z. Chojnicki, Zastosowanie modeli grawitacji..., passim.

27 J. Barbour, op. cit. 
np. modele rozwoju miast, wpisane w paradygmat rozwoju zrównoważonego $^{28}$. W obu przypadkach, tj. zarówno paradygmatów, jak i modeli, mamy do czynienia $\mathrm{z}$ zastosowaniem analogii, a ponadto i modele, i paradygmaty maja charakter otwarty ${ }^{29}$. Moga być korygowane, uzupełniane, zmieniane i zastępowane nowymi. Tak pojmowane pełnia w nauce wiele ważnych funkcji, zarówno teoretycznych, jak i praktycznych. Ich nazwy, bez względu na to, czy sa nowe czy tradycyjne, wchodzą w skład języka naukowego.

\section{ZAPOŻYCZENIA OBCOJĘZYCZNE, NEOLOGIZMY ORAZ NIEPOTRZEBNE MNOŻENIE I POSZERZANIE POJĘĆ JAKO WYRAZ INFLACJI TERMINOLOGICZNO-POJĘCIOWEJ W JĘZYKU NAUKOWYM}

Inną charakterystyczną cechą języka nauk społecznych i ekonomicznych, choć nie tylko, obok metafor, znajdujacych sensowne zastosowanie przede wszystkim w nazywaniu formułowanych paradygmatów i budowanych modeli oraz ich składników, jest rozszerzanie znaczenia pojęć (terminów) istniejących, mnogość wprowadzanych do tego języka neologizmów, zapożyczeń z obcych języków, przyjmowanych w wersji oryginalnej lub tłumaczonej oraz wprowadzanie w użycie innych tzw. wyrazów pochodnych. Na szczęście wiele z tych nowych pojęć lub pojęciowych rozszerzeń nie jest wymysłem nauki, lecz wprowadzonych zostało do języka naukowego przez ,język urzędowy”, przede wszystkim dokumentów prawnych i upowszechnianych przez te dokumenty oraz media. Niestety, wiele z tych nowych terminów niczego do języka naukowego nie wnosi. Najczęściej są to synonimy znanych i utrwalonych w języku naukowym pojęć lub pojęcia zupełnie niepotrzebnie tworzone. Poniżej podane zostana jedynie wybrane przykłady słowotwórstwa naukowego ostatnich lat.

\section{Rozszerzanie znanych i stosowanych pojęć języka naukowego}

Wydaje się, że dobrym przykładem niepotrzebnego rozszerzania znaczenia pojęć znanych i tworzenia wyrazów pochodnych jest ustawa o planowaniu i zagospodarowaniu przestrzennym z 27 marca 2003 r. (wersja znowelizowana na koniec 2015 r.). Jest to jednocześnie przykład udziału polskiego prawodawstwa we wzbogacaniu języka naukowego. To w tym akcie prawnym, zupełnie niepotrzebnie, wprowadza się nowe kategorie obszarów będących przedmiotem planowania i gospodarki przestrzennej, takie jak: obszary funkcjonalne

${ }^{28}$ L. Mierzejewska, Rozwój zrównoważony miasta. Zagadnienia poznawcze i praktyczne, Bogucki Wydawnictwo Naukowe, Poznań 2009; J. Parysek, Urbanizacja i niektóre współczesne idee, koncepcje i modele planowania rozwoju miast, w: J. Słodczyk, M. Śmigielska (red.), Wspótczesne kierunki i wymiary procesów urbanizacji, Wyd. UO, Opole 2008, s. 11-26; J. Parysek, Wspótczesne miasta i problemy ich funkcjonowania i rozwoju, w: idem (red.), Kształtowanie przestrzeni miejskiej: aspekty teoretyczne i praktyczne, UAM, WPA, Poznań-Kalisz 2012, s. 9-57.

${ }^{29}$ J. Barbour, op. cit. 
różnych kategorii (miejskie obszary funkcjonalne ośrodków: wojewódzkich, regionalnych, subregionalnych i lokalnych, wiejskie obszary funkcjonalne: rozwojowe $i$ wymagajace wsparcia), a także szczególnie niejasną i zróżnicowaną kategorię: obszarów funkcjonalnych szczególnych zjawisk oraz dodatkowo obszar zwiazku metropolitalnego. Czyni to chaos terminologiczno-pojęciowy, a ponadto wprowadza w obieg klasyfikacje, które ani nie sa adekwatne, ani rozłączne, a zatem nie sa poprawne z punktu widzenia teorii klasyfikacji ${ }^{30}$. $\mathrm{W}$ teorii geografii oraz gospodarki regionalnej i przestrzennej przedmiotem badania, poznania i działania jest region, zarówno węzłowy (funkcjonalny), jak i jednorodny (strukturalny). Tego rodzaju obszary (regiony) sa także przedmiotem planowania i miejscami prowadzenia gospodarki przestrzennej. To dla wyróżnionych kategorii regionów oraz dla tzw. obszarów problemowych tradycyjnie opracowuje się plany zagospodarowania przestrzennego. Wymienione dwie kategorie regionów (węzłowe i jednorodne) oraz obszary problemowe wyczerpuja, jak się wydaje, wszystkie potrzeby praktyki planowania. Oznacza to, że przedmiotem planowania (i gospodarki przestrzennej) powinny pozostawać jedynie: jednostki terytorialnego podziału kraju (regiony węzłowe), sensownie wydzielone aglomeracje (regiony węzłowe) oraz obszary problemowe (regiony jednorodne). Nie ma więc potrzeby tworzenia innych pojęć, co najwyżej potrzebne jest szczegółowe ich nazwanie w konkretnych przypadkach (np. województwo pomorskie, gmina Tarnowo Podgórne, aglomeracja górnoślaska, Puszcza Białowieska, Dolina Noteci).

W tym kontekście rozważań można także wskazać na kompletnie nietrafione zastosowanie znanego z matematyki i fizyki pojęcia, jakim jest symetria, a właściwie asymetria. W publikacjach naukowych można bowiem znaleźć sformułowanie asymetria informacji czy asymetria danych. Metafora ta nie ma jednak nic wspólnego z tym, co można by łączyć z symetrycznością (niesymetrycznościa). Chodzi bowiem o tendencyjne czy manipulacyjne wykorzystywanie informacji i danych liczbowych, z czym właściwie mamy do czynienie od zarania cywilizacji, a co nabiera szczególnego znaczenia w czasach panującej poprawności politycznej. Termin ten wiele obiecuje, a jest jedynie zakamuflowaniem istoty sprawy, która jest tendencyjny, subiektywny, nieuczciwy dobór i wykorzystanie informacji, co z żadną asymetrią nie ma nic wspólnego.

Innym z pojęć wprowadzonych do języka naukowego i ugruntowywanego przez dokumenty jest termin interesariusz, o którym szerzej poniżej.

\section{Pojęcia rozmyte jako efekt obcojęzycznych zapożyczeń i nieszczęśliwych tłumaczeń}

Dobrym przykładem w tym zakresie jest wspomniany powyżej termin interesariusz, obecny m.in. w tekście ustawy z 9 października 2015 r. o rewitalizacji i w tym akcie prawnym zdefiniowany (ang. stakeholder). Zgodnie z treścią tej ustawy (art. 2) rewitalizacja prowadzona będzie (podmioty rewitalizacji) przez „interesariuszy rewitalizacji na podstawie gminnego programu rewitalizacji”.

${ }^{30}$ J. Parysek, Modele klasyfikacji w geografii, WN UAM, Poznań 1982. 
Interesariuszami zaś sa, zgodnie z treścią tej ustawy (art. 2): „(1) mieszkańcy obszaru rewitalizacji oraz właściciele, użytkownicy wieczyści nieruchomości i podmioty zarządzające nieruchomościami znajdujacymi się na tym obszarze, w tym spółdzielnie mieszkaniowe, wspólnoty mieszkaniowe i towarzystwa budownictwa społecznego; (2) mieszkańcy gminy inni niż wymienieni w pkt 1; (3) podmioty prowadzace lub zamierzajace prowadzić na obszarze gminy działalność gospodarcza; (4) podmioty prowadzące lub zamierzające prowadzić na obszarze gminy działalność społeczna, w tym organizacje pozarządowe i grupy nieformalne; (5) jednostki samorządu terytorialnego i ich jednostki organizacyjne; (6) organy władzy publicznej; (7) podmioty, inne niż wymienione w pkt 6 , realizujace na obszarze rewitalizacji uprawnienia Skarbu Państwa”. Innymi słowy - wszystkie podmioty prawne oraz wszystkie osoby i organizacje społeczne, jakie znajduja się na terenie gminy i realizują tam swoje cele. Pod pojęciem interesariusz kryje się więc wiele osób, instytucji, organizacji, firm itp., co oznacza, że termin ten niczego nie precyzuje. Może brzmi nowocześnie, postępowo i zgodnie z duchem czasu, a ponadto dalej zakończeniem ,-iusz” nawiąuje do takich nazw, jak: emisariusz, woluntariusz, sanitariusz, notariusz, antykwariusz, akcjonariusz, ordynariusz, templariusz, utracjusz, funkcjonariusz, parlamentariusz czy proletariusz (starsi wiedza, kto to taki). Jest jednak pewna różnica. W podanych powyżej przykładach dokładnie wiadomo, o kogo chodzi i jaka pełni funkcję. Jako pojęcie interesariusz w istocie rzeczy niczego nie wyraża, nie wyjaśnia, nie precyzuje ani nie uszczegółowia. Trudno też dociec, co nowego definiuje, lepiej ujmuje, określa, interpretuje, wymiaruje. Rodzi się zatem pytanie, jaki jest sens wprowadzenia do języka polskiego, zwłaszcza naukowego, takiego niedookreślonego i rozmytego semantycznie pojęcia ${ }^{31}$. Czy zatem w odniesieniu do rewitalizacji, ale także i do planowania oraz gospodarki przestrzennej, nie byłoby lepiej wyróżnić jednoznacznie określone podmioty względnie realizatorów (uczestników) projektu (procesu) oraz beneficjentów zrealizowanych zamierzeń? ${ }^{32}$ Podmiotami i przedmiotami żadnej decyzji nie moga być realnie wszyscy mieszkańcy danej jednostki terytorialnej, wszyscy bowiem praktycznie oznacza, że nikt - i w tym tkwi problem interesariusza.

Jest wiele innych wprowadzanych do języka naukowego obcojęzycznych zapożyczeń przyjmowanych w oryginalnej wersji lub w dość dziwnym tłumaczeniu. Jednym z takich wyrazów jest przymiotnik smart tłumaczony przede wszystkim - i chyba niezbyt trafnie - jako inteligentny i podobnie jak interesariusz niezwykle ochoczo przyjmowany. Przymiotnik smart przyjmuje w języku angielskim wiele znaczeń. Smart to coś, co jest przede wszystkim eleganckie, wykwintne, wytworne, gustowne - i w takim sensie wyraz ten stosowany był już przez II wojną światowa, np. w odniesieniu do osób i mody (smart lady, smart suit). Być może kłopoty $\mathrm{z}$ doborem odpowiedniego polskiego tłumaczenia sprawiły, że w użyciu znajduje się także termin oryginalny, tj. smart, niestety rozumiany jako inteligentny. Można oczywiście przyjąć, że efektem

${ }^{31}$ Warto w tym miejscu przypomnieć, że interesariusz jest pojęciem powstałym na potrzeby zarządzania projektami i zarządzania strategicznego i tam znaczenie pojęcia jest doprecyzowane.

${ }^{32}$ Terminy: beneficjum, beneficja, beneficjent, choć wywodzące się z języka łacińskiego, od wieków obecne są w języku polskim i jednoznacznie rozumiane. 
aktualnie podejmowanych, konkretnych działań będą smart: regiony, miasta, gospodarka, dziedziny gospodarki, przemysł, infrastruktura, technologia, specjalizacje, działania i wiele jeszcze innych rzeczy. Dlaczego jednak maja być inteligentne, kiedy ta właściwość (inteligencja) przysługuje ludziom (przynajmniej niektórym)? Jest to zaprzeczeniem istoty rozwoju cywilizacyjno-kulturowego, którego czynnikiem, obok wiedzy i doświadczenia, jest na razie ciagle jeszcze ludzka inteligencja (będąca w warunkiem twórczości naukowej i specjalizacji). Jest jednak, jak się wydaje, pewne uzasadnienie przyjęcia słowa smart w określeniu paradygmatu rozwoju gospodarczego określanego metaforą smart growth $h^{33}$. Można także, jak się zdaje, mówić o miastach smart (smart city), których rozwój kształtowany jest czy przebiega w ramach paradygmatu smart growth (np. Seattle i Portland w USA oraz Vancouver i Victoria w Kanadzie). Budowany w ramach tego paradygmatu (smart growth) model smart city jest oczywiście do zaakceptowania, jednakże pod warunkiem dokładnego, jednoznacznego i sensownego zdefiniowania cech takiego miasta. Bogata literatura wskazuje jednak na to, że miasta inteligentne sa jednak rozmaicie definiowane, katalogi ich cech są niezwykle pojemne, a inteligencja miast dość dowolnie określana. W świetle treści literatury, w której zdefiniowano paradygmat smart growth, miastem smart (znacznie lepiej smart niźli inteligentne) może być nazwane jedynie takie, w którym: 1) są różne formy użytkowania ziemi, 2) dominuje zwarta zabudowa, 3) istnieje zróżnicowana: rodzajowo, wielkościowo i cenowo, oferta budownictwa mieszkaniowego, 4) tworzone sa jednostki urbanistyczne, gdzie w zasięgu dojścia pieszego zrealizować można podstawowe potrzeby gospodarstw domowych, 5) zachowane są większe obszary otwarte, chronione są tereny użytkowane rolniczo i naturalne piękno oraz rozwiązywane sa problemy tych obszarów, 6) rozwój ukierunkowany jest na potrzeby społeczności lokalnych i rozwiązywanie ich problemów, 7) istnieje możliwość korzystania z różnego rodzaju środków transportu, z wyraźną preferencją transportu publicznego, 8) podejmowane sa czytelne i uczciwe decyzje dotyczące efektywnego ekonomicznie i społecznie rozwoju i zagospodarowania przestrzennego, o możliwych do przewidzenia konsekwencjach, 9) funkcjonuje dobrze wychowana, odpowiedzialna i atrakcyjna społeczność lokalna, o emocjonalnym związku z miejscem zamieszkania, 10) wzmacniana jest współpraca władz lokalnych, właścicieli nieruchomości oraz inwestorów w procesie podejmowaniu decyzji związanych $\mathrm{z}$ rozwojem i zagospodarowaniem przestrzennym jednostki urbanistycznej ${ }^{34}$. I co to ma wspólnego z inteligencją?

Innym przykładem powszechnego niemal zastosowania jest może nie tyle metafora rozwój zrównoważony, ile przymiotnik zrównoważony, odnoszony do różnych dziedzin życia społeczno-gospodarczego. Mamy więc zrównoważony rozwój, zrównoważoną gospodarkę, zrównoważony układ komunikacyj-

${ }^{33}$ A. Downs, What does smart growth really mean?, „Planning” 64(4), 2001, s. 20-25; G. C. Dale, Smart growth, „Planning Commissioners Journal” 50(Spring), 2003; P. Filion, Towards smart growth: the difficult implementation of alternatives to urban dispersion, „Canadian Journal of Urban Research” 12(1), 2003, s. 48-60; J. Parysek, Wspótczesne miasta i problemy..., passim.

${ }^{34}$ A. Downs, op. cit.; P. Filion, op. cit.; J. Parysek, Wspótczesne miasta i problemy..., passim. 
ny, zrównoważony transport publiczny, zrównoważoną turystykę, rekreację itd. Mamy także uchwalonych wiele strategii zrównoważonego rozwoju miast i gmin bez określenia, na czym to zrównoważenie ma polegać. Jeśli rozwój zrównoważony, jako paradygmat rozwoju społeczno-gospodarczego, został w pewien sposób zdefiniowany, to tego samego należałoby oczekiwać od modeli rozwoju zrównoważonego, zarówno jednostek terytorialnych, jak i poszczególnych dziedzin gospodarki ${ }^{35}$.

Podobny „uniwersalny” charakter ma słowo zarzadzanie, będące w coraz bardziej powszechnym użyciu. Jest wiele definicji zarządzania kładących nacisk na osiaganie określonych celów. Bardzo ogólna definicja za zarządzanie uważa sztukę osiagania zamierzonych celów i tak sformułowana niewiele się różni od arystotelesowskiej definicji polityki, a także od definicji planowania, którą od 50 lat przytacza autor niniejszego opracowania studentom w sformułowaniu: „planowanie jest procesem budowy planu, będącego zbiorem decyzji, projektów decyzji i przewidywań, prowadzących do realizacji określonego celu" (najczęściej ma to zwiąek z planowaniem przestrzennym i celem jest uzyskanie określonego stanu ładu przestrzennego na danym terenie). Można zatem sformułować pytanie: Czy jest jakaś różnica między planowaniem a zarządzaniem? Chyba tak, ale podane powyżej definicje tego nie wskazują. Inna, też bardzo ogólna definicja, traktuje zrządzanie jako umiejętność wychodzenia z chaosu, innymi słowy - jako umiejętność zaprowadzania ładu czy porządku, co jest chyba zbytnim uproszczeniem istoty sprawy. Generalnie jednak za zarządzanie uważa się działalność kierownicza, obejmujacą m.in.: planowanie, organizowanie, decydowanie, koordynowanie i kontrolowanie. Czy jednak wszystkim można zarządzać? Gospodarką zapewne tak, rozwojem też, oczywiście przedsiębiorstwem, chyba także miastem, gmina, województwem, prawdopodobnie również: jakością produkowanych wyrobów, finansami, zasobami ludzkimi oraz czasem. Ale czy można zarządzać: bezrobociem, kosztami, kryzysem, zobowiązaniami, długami, ubóstwem itp.? Czy nie lepiej mówić o rozwiązywaniu problemów bezrobocia, o sposobach kształtowaniu kosztów, sposobach wychodzenia z kryzysu, wywiązywania się ze zobowiązań, sposobach spłaty zadłużenia czy wychodzenia z długów, przeciwdziałaniu ubóstwu itp.? Wydaje się, że tak. Dla takiego śmiertelnika, jak autor niniejszego tekstu bardziej zrozumiałe jest jednak zawsze to, co od dawna ma swój sens, choć może nie jest tak „naukowe” w brzmieniu. Oczywiście powyższe uwagi nie mają nic wspólnego z krytyka „organizacji i zarządzania”, jako dziedziny nauk ekonomicznych, jednakże ta odnosi się przede wszystkim do zarządzania gospodarczego w różnej skali ${ }^{36}$. Rozwijajac język naukowy, warto jednak pamiętać o tym, że nie wszystko może i musi być zrównoważone, podobnie i o tym, że nie wszystkim można zarządzać.

\footnotetext{
${ }^{35}$ Podana w ustawie z 7 kwietnia 2001 r. - Prawo ochrony środowiska definicja rozwoju zrównoważonego jest bardzo ogólna i nawiązuje do definicji funkcjonujących w agendach środowiskowych ONZ.

${ }^{36}$ A. K. Koźmiński, W. Piotrowski, Zarzqdzanie. Teoria i praktyka, PWN, Warszawa 2009; A. Stabryła, Podstawy organizacji $i$ zarzqdzania. Podejście i koncepcje badawcze, Wyd. UEK, Kraków 2012.
} 
Wieloznaczność jest też charakterystyczną cechą modnej metafory mapa drogowa. Terminem tym zastępuje się takie ugruntowane w języku nie tylko naukowym i od dawna stosowane pojęcia, jak: plan, projekt, program, strategia, scenariusz, schemat itp. Może to brzmi i ładnie. Odnoszone jest do sposobów i metod osiagania określonych celów, jest więc i jakáś drogą prowadząca do celu. Zapewne i pokazuje, jak przebiega ta droga, więc nawiązuje także do mapy. Wszystko to wydaje się uzasadniać wprowadzenie do języka tej metafory, ale czy wnosi coś nowego w stosunku do pojęć wymienionych powyżej, które są dobrze zdefiniowane i do tego semantycznie jasne i rozłączne?

\section{Zbyteczne synonimy (substytuty pojęciowe)}

W przypadku wprowadzania nowych pojęć bez wątpienia ważna jest konfrontacja znaczenia tego pojęcia z tymi, jakie sa od dawna stosowane i jednoznacznie rozumiane $\mathrm{w}$ nauce, $\mathrm{w}$ tym w przyjmowanych ideach, koncepcjach, modelach i paradygmatach. Jakoś dziwnie się składa, że znane i od dawna stosowane pojęcie czynników rozwoju jest zastępowane przez przeróżne synonimy, które wprowadzając nieporozumienia, rodza pytania o ich wartość semantyczna, a dalej o sens ich wprowadzenia do języka naukowego.

Czynnik to nic innego, jak przyczyna danego zjawiska, powodująca określony skutek. W tym znaczeniu czynnikami rozwoju społeczno-gospodarczego są przyczyny powodujące taki (konkretny) rozwój czy wzrost ${ }^{37}$. Innymi słowy, obserwowany rozwój (wzrost) jest w pewnym sensie wypadkową wykorzystania czynników. Oczywiście wpływ na oba te procesy (rozwój i wzrost) maja nie tylko czynniki, ale także uwarunkowania rozwoju, których oddziaływanie modyfikuja dodatkowo występujące bariery (wzrostu, rozwoju) ${ }^{38}$. Nie wiadomo zatem, jaki jest sens zastępowania czynników rozwoju przez takie, w istocie rzeczy metafory, jak: maszyny, generatory, silniki, koła zamachowe, napędy, paliwa, lokomotywy, wehikuty, bieguny czy potencjaty rozwoju ${ }^{39}$. W tabeli 1 zawarte są domeny wyjściowe i docelowe wymienionych synonimów czynników rozwoju. Analizując zawartość tabeli 1, nie można nie dojść do wniosku, że przytoczone metafory w gruncie rzeczy odnoszą się do tego, co tradycyjnie, z jednej strony, nazwać można przede wszystkim czynnikami, a z drugiej - co wiązać, choć w mniejszym stopniu, można z paradygmatami, a także modelami rozwoju. Takim substytutem innych pojęć jest oczywiście wspomniana powyżej mapa drogowa.

${ }^{37}$ Różnice między rozumieniem rozwoju i wzrostu gospodarczego nie będą w tym miejscu rozpatrywane.

${ }_{38}$ W. Maik, J. Parysek, L. Wojtasiewicz, Bariery wzrostu w gospodarce przestrzennej, Biuletyn Komitetu Przestrzennego Zagospodarowania Kraju PAN 99, Warszawa 1978.

${ }^{39}$ Nie chodzi w tym przypadku ani o „bieguny wzrostu”, których koncepcję sformułował F. Perroux, ani o potencjał geograficzny (por. J. Grzeszczak, Bieguny wzrostu a formy przestrzeni spolaryzowanej, Instytut Geografii i Przestrzennego Zagospodarowania PAN, Prace Geograficzne 173, Continuo, Wrocław 1999; R. Domański, Gospodarka przestrzenna, PWN, Warszawa 1990; G. Benko, Geografia technopolii, PWN, Warszawa 1993; J. Parysek, Podstawy gospodarki lokalnej, WN UAM, Poznań 1997; Z. Chojnicki, T. Czyż, W. Ratajczak, Model potencjału: podstawy teoretyczne $i$ zastosowanie $w$ badaniach przestrzenno-ekonomicznych i regionalnych, Bogucki Wydawnictwo Naukowe, Poznań 2011). 
Tabela 1

Wybrane przykłady metafor dotyczących rozwoju społeczno-gospodarczego (substytutów czynników rozwoju)

\begin{tabular}{|c|c|c|}
\hline $\begin{array}{l}\text { Domena } \\
\text { źródłowa }\end{array}$ & Objaśnienia & $\begin{array}{l}\text { Domena/y } \\
\text { docelowa/e }\end{array}$ \\
\hline Potencjał & $\begin{array}{l}\text { Stan pola grawitacyjnego, elektro- } \\
\text { magnetycznego, wypadkowa działa- } \\
\text { nia sił pola i oporu odległości }\end{array}$ & Potencjał rozwojowy (rozwoju) \\
\hline Lokomotywa & $\begin{array}{l}\text { Pojazd mechaniczny przeznaczony } \\
\text { do ciagnięcia wagonów po przygoto- } \\
\text { wanym torze }\end{array}$ & Lokomotywa/y rozwoju \\
\hline Generator & $\begin{array}{l}\text { Urządzenie (maszyna) do wytwa- } \\
\text { rzania czegoś (prądu, drgań, pola } \\
\text { elektrycznego, pola magnetycznego, } \\
\text { pola elektromagnetycznego, dźwię- } \\
\text { ku itp.) }\end{array}$ & Generator rozwoju \\
\hline $\begin{array}{l}\text { Maszyny } \\
\text { (motory, silniki, } \\
\text { napędy, koła } \\
\text { zamachowe) }\end{array}$ & $\begin{array}{l}\text { Urządzenia zastępujące prace ludz- } \\
\text { ka, jednostki napędowe i wspoma- } \\
\text { gające ruch innych urządzeń }\end{array}$ & $\begin{array}{l}\text { Maszyny, motory, silniki, napędy, } \\
\text { koła zamachowe itp. rozwoju (go- } \\
\text { spodarki) }\end{array}$ \\
\hline Bieguny & $\begin{array}{l}\text { Przeciwległe końce magnesu (elek- } \\
\text { tromagnesu), bieguny Ziemi }\end{array}$ & Bieguny wzrostu (rozwoju) \\
\hline Trajektoria & $\begin{array}{l}\text { Krzywa zakreślona przez porusza- } \\
\text { jące się ciało; tor pocisku }\end{array}$ & Trajektorie rozwoju \\
\hline Paliwo & $\begin{array}{l}\text { Substancja wydzielające podczas } \\
\text { spalania duże ilości ciepła (nośnik } \\
\text { energii) }\end{array}$ & $\begin{array}{l}\text { Paliwo napędowe } \\
\text { gospodarki }\end{array}$ \\
\hline
\end{tabular}

Źródło: opracowanie własne.

\section{Personifikacja rzeczy, zdarzeń i procesów}

Do innych, charakterystycznych i generalnie niekorzystnych dla języka naukowego, a także poprawności języka polskiego cech należy personifikacja rzeczy, w mniejszym stopniu zdarzeń i procesów. Personifikacja jest metaforyczne utożsamianie przedmiotów, rzeczy, roślin, zwierząt, także zjawisk, procesów, idei - z osobami, względnie przypisywanie im cech ludzkich. W języku literackim personifikowanie „nie-osób” jest od wieków ugruntowaną tradycja. W języku naukowym jest czymś raczej nowym. Znaleźć można oczywiście wiele uzasadnionych personifikacji rzeczy. Uzasadnione wydaje się też metaforyczne przypisywanie cech lub procesów właściwych organizmom żywym niematerialnym obiektom. Jest to jednak uzasadnione jedynie wtedy, kiedy rozwiązanie takie wnosi coś nowego w sferę poznania ${ }^{40}$. Nie wiadomo, co nowe-

${ }^{40}$ Autor niniejszego opracowania wprowadził, ale jednocześnie dokładnie, w nawiązaniu do organicystycznego modelu systemowego, opisał metaforę życie miasta (por. J. Parysek, Life of the city, w: L. Mierzejewska, J. Parysek (eds.), Cities in Complex World, Bogucki Wydawnictwo 
go wnosi nazywanie wszystkiego co nowe, nowoczesne, innowacyjne, kreatywne - inteligentnym, podobnie dlaczego miasta, regiony, technologie, techniki, dziedziny gospodarki, branże, nazywane są inteligentnymi, na co już zwracano uwagę. Jest to może konsekwencja tego, że kiedyś były to uczace się miasta, regiony, gospodarki i dzięki temu stały się inteligentne, choć inteligencja jest raczej cechą wrodzona, właściwą konkretnym umysłom ludzkim. Inteligencja jest zespołem zdolności psychicznych umożliwiających danej osobie (osobnikowi) sprawne korzystanie z nabytych umiejętności i przejawianie skutecznego zachowania się w nowej, nieznanej sytuacji ${ }^{41}$. Nieodłącznym atrybutem inteligencji jest zaś myślenie. Przyjąć oczywiście można, że proces uczenia się (ludzi, nie miast ani regionów) prowadzić może do zwiększenia poziom inteligencji, ale na ten proces wpływ ma, jak się wydaje, wiele innych czynników. Obok inteligentnych mamy też kreatywne: regiony, miasta, dziedziny gospodarki, choć kreatywność podyktowana jest możliwościami intelektualnymi, określanymi mianem talentu, warunkowanego wrodzonymi uzdolnieniami i predyspozycjami w dziedzinie intelektualnej (także artystycznej, sportowej, fachowej). Zróżnicowany na przestrzeni wieków i lat rozwój miast, regionów, gospodarki (prosperity i kryzysy, rozkwit i upadek), jakoś nie bardzo uzasadnia potraktowanie kreatywności jako wrodzonej ich cechy, nawet w sytuacji kiedy mamy do czynienia z ich genius loci. Wobec takich tendencji można jedynie zalecać pewien umiar oraz poszukiwanie racjonalnych uzasadnień personifikacji.

\section{ZAKOŃCZENIE}

Proces upowszechniania w języku naukowym nowych pojęć, bez względu na ich pochodzenie, przypomina znane z literatury dotyczącej badań przestrzenno-ekonomicznych (choć nie tylko), procesy dyfuzji przestrzennej. Tego rodzaju problematyka została podjęta w latach sześćdziesiątych, a celem prowadzonych badań było opisanie i wyjaśnienie procesu rozprzestrzeniania się różnego rodzaju innowacji ${ }^{42}$. Oczywiście podejmowana była także problematyka rozprzestrzeniania się nie tylko innowacji, lecz także: nowych artykułów powszechnego użytku, pomysłów i propozycji projektantów mody (ubiory), pokarmów (fast food), modeli konsumpcji, wzorców zachowań, przebojów muzyki popularnej, chorób zakaźnych i psychicznych, patologii społecznych itp., choć

Naukowe, Poznań 2014, s. 213-224; eidem, Życie miasta: studium Poznania. Miasto i jego mieszkańcy, Bogucki Wydawnictwo Naukowe, Poznań 2013; eidem, Życie miasta: studium Poznania. Infrastruktura miejska, Bogucki Wydawnictwo Naukowe, Poznań 2014; J. Parysek, Miasto w ujęciu systemowym, „Ruch Prawniczy, Ekonomiczny i Socjologiczny” 77(1), 2015, s. 27-53.

${ }_{41}$ A. Sadowski, J. A. Chmurzyński, Biologiczne mechanizmy zachowania, PWN, Warszawa 1989.

${ }^{42}$ Proces ten jako pierwszy opisał szwedzki geograf T. Hägerstrandt (por. idem, Innovation Diffusion as a Spatial Process, UCP, Chicago 1967; R. Domański, Teoretyczne podstawy geografii ekonomicznej, PWN, Warszawa 1982; J. Łoboda, Rozwój koncepcji i modeli przestrzennej dyfuzji innowacji, Acta Universitatis Wratislaviensis, 585, Studia Geograficzne 37, Wrocław 1983; Z. Kamiński, Przestrzenna dyfuzja innowacji rolniczych, Geografia 25, WN UAM, Poznań 1982; J. Parysek, Podstawy gospodarki lokalnej, WN UAM, Poznań 1997. 
nie zawsze z zastosowaniem zaawansowanych technik badawczych i w celach naukowych. W prowadzonych badaniach nad dyfuzją uwzględniane są różne klasyfikacje procesów dyfuzyjnych, czyli rozprzestrzeniania się innowacji, od miejsca jej powstania do miejsca adaptacji. Wydaje się, że dyfuzja innowacji terminologiczno-pojęciowych może być interpretowana w ramach każdej z wydzielonych klas typologicznych, zwłaszcza dyfuzji ekspansywnej i epidemiologicznej. Przykładowo, w dyfuzji ekspansywnej proces transmisji innowacji dokonuje się z jednego miejsca (jednej jednostki) do miejsc sasiednich (sasiednich jednostek) lub sasiednich punktów decyzyjnych. W przypadku języka naukowego z jednej dziedziny do innej, z jednej publikacji do kolejnych. Proces ten może w rzeczywistości zostać zwielokrotniony lub zatrzymany. Obecnie mamy do czynienia raczej z tym pierwszym, o czym świadczy niezwykła popularność stosowania w języku naukowym, mówiąc ogólnie, neologizmów. W dyfuzji epidemicznej przebieg procesu zależny jest od bezpośredniego kontaktu (spotkanie, konferencja, media) i dokonuje się w sposób odśrodkowy, od miejsca powstania, z uwzględnieniem punktów adaptujących (zwolennicy nowej terminologii) i opornych względnie odpornych (przeciwnicy). Przebiega w zasadzie podobnie, choć różne są miejsca i sposoby adaptacji ${ }^{43}$.

Opisany powyżej proces świadczy niewątpliwie o tym, że język, jako środek porozumiewania się i komunikacji społecznej, znajduje się w procesie nieustannego rozwoju. Jest to nie tylko cecha języka codziennego, potocznego, w sposób szczególny literackiego, ale także naukowego. Maniera czy tendencja do tworzenie nowych pojęć, rozszerzenie znaczenia pojęć znanych, wprowadzenie obcojęzycznych, personifikacja „nie-osób” itp. dotyczą języka niemal wszystkich dyscyplin naukowych, jednakże w sposób szczególny jest obecna w naukach społecznych. Choć procesu tego nie uda się zatrzymać, to jednak przez środowiska naukowe podjęty powinien zostać wysiłek jego wyhamowania lub przynajmniej kontrolowania. W zmieniającym się świecie jest wiele takich sytuacji, w których niemal koniecznościa jest wprowadzenie nowego pojęcia - i taka jest kolej rzeczy. Substytucja znanego, dobrze zdefiniowanego, zrozumiałego i powszechnego w użyciu jest jednak nieporozumieniem. Prowadzi do tego, co niektórzy nazywają uprawianiem pseudonauki. Opisany w niniejszym artykule proces toczy się, jakby zapomniano o tym, że już w XIV w., wspomniany uprzednio angielski mnich William Ockham sformułował zasade prostoty (pierwszeństwa prostoty nad złożonościa) nazwaną brzytwą Ockhama. Może więc warto sobie o tym przypomnieć, oddając się zajęciu tworzenia nowych, nie zawsze uzasadnionych i potrzebnych pojęć, że nie ma potrzeby ich mnożenia ponad niezbędną konieczność. Troska o język ojczysty i jego poprawność należy do obowiązku każdego obywatela ${ }^{44}$. Poprawność języka naukowe-

${ }_{43}^{4}$ T. Hägerstrandt, op. cit.; R. Domański, op. cit.; J. Łoboda, op. cit.; Z. Kamiński, op. cit.; J. Parysek, Podstawy gospodarki..., passim.

${ }^{44}$ Ma to zapewnić stosowanie ustawy z 7 października 1999 r. o języku polskim, której postanowieniami rzadko kto się przejmuje, także środowiska naukowe, choć ochrona języka składać się ma na ochronę tożsamości naukowej w procesie globalizacji. W niniejszym artykule globalizację uznano zaś za jeden z czynników zmian zachodzących w języku naukowym. W ustawie o języku polskim z rygorów zapisu wyłączono zwyczajowo stosowaną $\mathrm{w}$ języku naukowym terminologie (art. 11). 
go jest natomiast wyzwaniem dla środowisk naukowych, których zadaniem jest, przy okazji prowadzonych rozważań i badań, kształtowanie języka jasnego, prostego, logicznego, zwięzłego, jednoznacznego i zrozumiałego - i warto to mieć na uwadze.

prof. dr hab. Jerzy J. Parysek

Uniwersytet im. Adama Mickiewicza w Poznaniu

\section{METAPHORS AND NEOLOGISMS IN THE MODERN LANGUAGE OF SOCIAL AND ECONOMIC SCIENCE}

\section{Summary}

Together with the development of civilisation we observe a development of the language and not only the colloquial or literary but the language of science as well. The features of this development include, above all, metaphorisation of scientific language, borrowings from other languages (original and translated), and extension of the meaning of existing concepts. As a result, the scientific language, instead of being a tool of communication, causes more and more ambiguity, doubts and problems of interpretation. The selected examples of the changes occurring in the language of social and economic science presented in this article are intended to provoke a reflection on the on-going process which may lead, and does indeed, to many misunderstandings. Scientific language must be clear, simple, logical, concise, unambiguous and comprehensible. Only such will be capable of conveying the meaning of scientific research and investigation. This article presents the author's point of view and may be controversial but it is also intended to provoke a discussion. 